\title{
VERNACULAR ANSWERS TO SPATIAL NEEDS OF HUMAN ACTIVITIES: INDONESIAN HOUSES
}

\author{
Zuber Angkasa Wazir ${ }^{1 *}$, Irma Indriani ${ }^{2}$ \\ ${ }^{1}$ Departemen Arsitektur, Universitas Muhammadiyah Palembang, Jalan Jenderal Ahmad Yani 13 Ulu Seberang Ulu II, \\ Kec. Plaju, Sumatera Selatan 30116, Indonesia \\ ${ }^{2}$ Departemen Arsitektur, Universitas Tridinanti Palembang, Jalan Kapten Marzuki 2446 Kamboja Palembang, \\ Sumatera Selatan 30129, Indonesia \\ *Corresponding author; Email: zuber_angkasa@um-palembang.ac.id
}

\begin{abstract}
This study seeks to identify the variation of vernacular house designs in Indonesia and the strengths and weaknesses of them, in relation to their service to human activities for mass-produced houses. It used a literature study approach by reviewing various studies on vernacular houses. A total of 51 houses from 31 ethnics and 28 provinces were reviewed and compared to find common relations between the activities and dimensions of the vernacular space. We found nine typologies based on space flexibility, distance from the ground, kitchen position, gender segregation, house mobility, sun-related orientation, openings extensivity, aisle existence, and privacy. A classification system was created based on typologies and evaluated the strengths and weaknesses of 15 houses from 14 ethnics. The finding is expected to be a reference for developing simple, mass-built houses considering the habits of local residents, and to build comprehensive classification systems for vernacular houses in Indonesia.
\end{abstract}

Keywords: Vernacular house; living activities; spatial needs; space size; space functional flexibility.

\section{INTRODUCTION}

Indonesia is a country with very wide variations of vernacular houses. These are parallel with the large ethnic diversity. Corresponding with the idea of vernacular houses in general, home functionality in Indonesia is more complex because it does not only provide the function of daily physical activities but also to give spiritual needs and deeper meaning (Dewi, 2003). As a result, a space with the same physical function may have different dimensions because of different spiritual needs and meanings.

The preservation of vernacular houses is very important nowadays to stimulate senses and give sensitivity to be parts of society (Wassum, 2013). Its rich existence and as far as relevant in urban topology can be maintained through local developers that are able to utilize local materials and methods with great cultural awareness (Ateshin, 1987). Vernacular houses can be adapted for small simple houses, such as state-subsidized houses. Furthermore, the use of traditional house design for subsidized houses has been implemented in Banjarmasin and positively responded by the banking (Banjarmasin Post, 2018).

The adequacy of spaces in mass-built housings today becomes an urgent issue because of the insufficiency and incompatibility between activities inside and spaces provided. The government intended to provide proper houses for lower-income people by implementing the one-million-houses program.
However, a number of problems can be identified as how narrow the space for family activities, the absence of a kitchen, a very small bath space, or a toilet facing the direction of qibla, that it is against the Islamic practice. This might happen since the architect did not consult the occupants about their space needs. Indeed, this is seldom considered necessary, especially to houses built in large quantities. However, Glassie (1990) emphasized that there was not an excuse for an architect to abandon the variation of human needs in a design.

Form change of a house cannot be separated from the activity patterns of the occupants (Faisal, 2018). Some of them may be modern, while others are culture-based. If the architect can create a functional but culturally sensitive house, the value of the house will increase and satisfy the occupants.

Vernacular houses, with long evolution, should accommodate the need of activities inside. A vernacular house shows climate, esthetics, socio-cultural, and spiritual aspects of a certain group of people (Tratsiakovich, 2018). Therefore, they are able to show the fulfillment of complex human living needs more than functional needs.

This research tried to provide alternative source to designers to build more functional spaces for human activities. To do this, we try to answer two questions. First, what is the variation of vernacular house designs that exist in Indonesia? Previous literature didn't answer this question yet. No exten- 
sive typologies of vernacular house designs exist in the scientific literature. One research from Faisal, Suwarno, \& Wihardyanto (2012) has created one typology: ventilation typology. There are many partial researches tried to learn specific house design. They have high detailed descriptions but blind with other house designs, such that no comparison tries to make between vernacular houses that exist in Indonesia. These researches then made some claims about the uniqueness of some researched houses, without trying to scan many other houses from other areas. We should then compose new typologies to better understand the variation. We even try to create a new classification system to identify a house characteristic. The second question is what the strengths and weaknesses of vernacular houses designs from Indonesia are, in relation to its service to human activities. We use the variations of Indonesian houses to test their power for modern purposes. This is the practical aspect of the research. Practitioners can get inspiration from the strengths of these houses and try to overcome the weaknesses presented by the design.

\section{METHODOLOGY}

This research used the literature study approach. The keyword "vernacular house" combined with "Indonesia" are to find studies about vernacular houses in Indonesia in Google Scholar and Google Book. We use two steps searching heuristics to find the articles. First, we downloaded all open access articles from the first ten pages from Google Scholar without time restriction. Second, we downloaded all open access articles from the first ten pages of Google Scholar search results with a time range from 2015 to today. For Google Book, we used the same keywords to search for books and read all open access books/book pages. All are classified according to the house researched.

To analyze the literature according to research purposes, the houses collected from literature then highlighted for their special features connected to the spatial needs of human activities. Afterwards, the unique characteristics of each house were compared to ones from another house. For example, for Minahasa's house, Toisi \& John (2012) highlighted that Minahasa house has an aisle that directs through the house, from the front door to the back door. It is a unique characteristic of Minahasa's house. For this, we search aisles in other houses from collected literature. We could find that Javanese houses do not have an aisle for privacy reasons. If the characteristics not mentioned in our collected literature, we return to search in Google Scholar. For this, we concluded that there are at least two types of the house based on aisle existence. The same heuristics were used for other reviewed the rest houses. We found nine typologies and description that are discussed in the results and discussion section.

The second question is what interpreted findings we could collect from the typologies related to modern users, by classifying the strengths and weaknesses of the houses. Eventually, we concluded what aspects from each house that can be adapted for the design of mass-built houses.

\section{RESULTS AND DISCUSSION}

There are 51 houses from 31 ethnics from 28 works of literature (Table 1). Though the number of the houses are quite low compared to Indonesian ethnics of 683 ranging from indigenous Indonesia, Arabic and Chinese (Hidayah, 2015). Most of these ethnics shared similar cultural features, especially those with closer geographic distance. The ethnics reviewed represented 28 provinces out of 34 provinces in Indonesia (figure 1). Next, we discuss the typology and the characteristics of several houses. Due to its completeness, only 15 out of 31 ethnics were reviewed for their houses' strengths and weaknesses.

\section{Flexibility}

The measurement of spaces in a house is an aspect that has low visibility because it is realized solely by the people who have access to the house (Brown \& Paddock, 2011). For such low visibility, the measurement of spaces is attempted as the practical benefits of the occupants. Only if the occupants have a higher social role, that they may have bigger spaces than the space needed. With this, the occupants can provide more spaces to anticipate a larger number of guests. The creation of larger spaces certainly requires more detailed construction and structure of the roof which are not affordable for people with less social roles. But if a house consists of one space, such a technical problem can be solved.

Houses at the south seaside of Pulau Seram, Maluku, were the simplest prototype of spatial divisions of living activities. The occupants explicitly have understood parts of the house. They know where to sleep, to relax, to gather with others, and a space to mingle with neighbors. The only space having borders is 'para-para' (attics) where physical activities are not carried out. Para-para is a chamber to store the family's belongings, i.e. weapons, human head/ skeleton as the result of initiation ritual, and treasure 


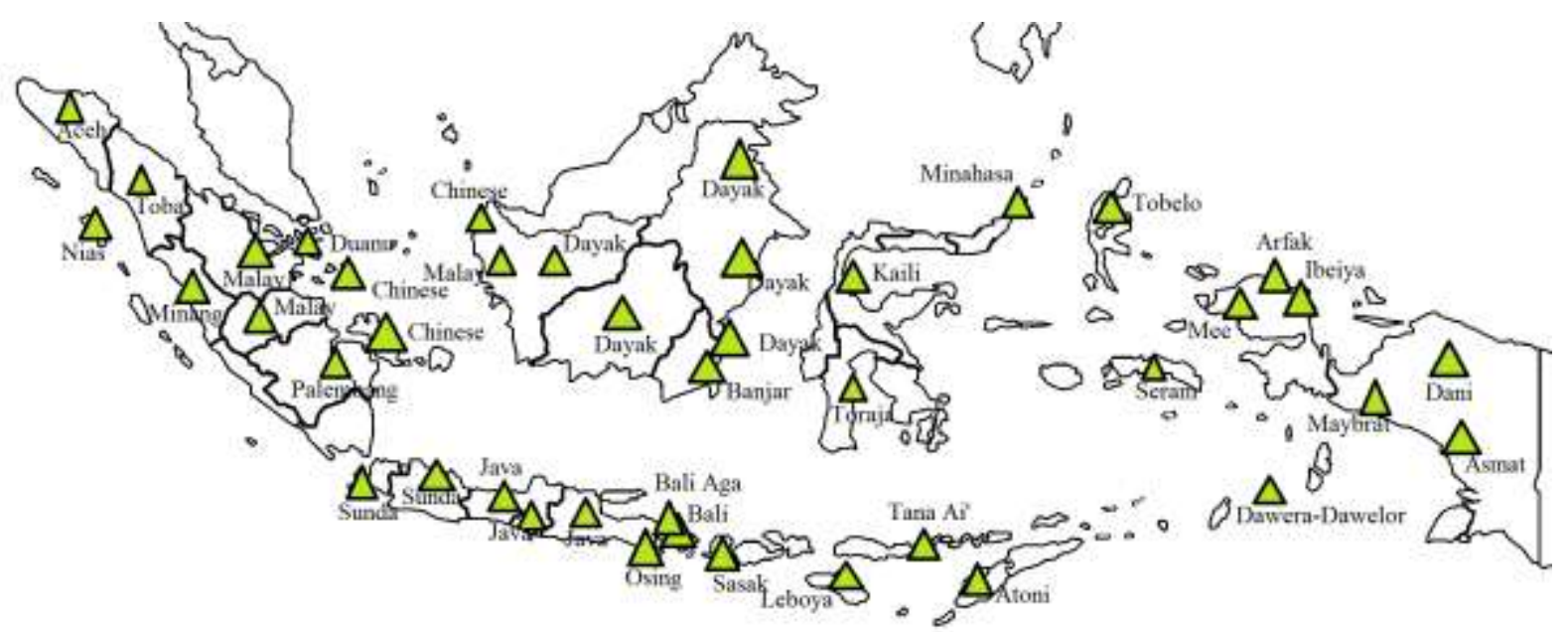

Fig. 1. Locations of ethnics reviewed in this research

(Wattimena, 2014). The division without partition can be found in houses in older Minahasa of North Sulawesi, Kaili of Central Sulawesi, and Toba of North Sumatra. One of the advantages of spaces without partition is the high quality of ventilation for the air circulation (Darragh, 2012).

Spacious multifunction rooms can be assumed as the characteristic of vernacular houses in Java. Studies on joglo houses built in Java lately showed that the occupants are consciously provided the pendopo to hold hajatan (parties). The organization of such events is seldom taken place. In daily conditions, this space is empty and quiet. In other houses, a kitchen that is very wide is actually used as a storage space and dining space without requiring a rigid partition. (Sardjono \& Nugroho, 2015).

Balinese houses are even more unique with several spaces stand by themselves. They are the modular type that has several spaces combined not with one whole solid construction, but with one area of land enclosed by walls. There is an empty land among buildings which become singled spaces. It reflects the flexibility of the space dimension for when it is needed, parts of the space can be extended without distracting the other parts of the house. However, it also introduced inflexibility, since it takes a lot of effort to extend space for a new purpose.

Different from traditional houses from South Seram that have high flexibility, Ibeiya houses from Moile ethnic in Pegunungan Arfak Regency, West Papua, are extreme sample of vernacular houses with very low flexibility. Activities inside Ibeiya houses are carried out in sitting position. They cover sleeping, chatting with other family members, or cooking. This does not mean that the height of the space is low. The interior height of Ibeiya houses is relatively as same as the common houses. The reason for sitting activities mostly is caused by the main function of the house is as a place for cooking. The fireplace is on the left and right sides of the house, beside the bed spaces of men and women. When the fireplace is set, the smoke will spread around the house causing the people standing inside may easily inhale the smoke. Furthermore, the reason to put the fireplace beside the house is as an adaptation towards the cold temperature of highlands.

Most vernacular houses are in between these two extreme points. Limas houses, as an example, are houses with high complexity. In front of the house, there is a jogan functioning as a working space. Jogan is just found in houses with four bengkilas. At the backside, there is amben that functions as balai or a place to discuss with the higher position for about 75 $\mathrm{cm}$. This higher position is automatically as a border including a clear border that the space has high public meaning. At the backside of amben, there is pangkeng, private space of the house owner. Pangkeng is a resting space of the occupants. Left pangkeng and left amben are separated from right pangkeng and right amben with an aisle. Between pangkeng and amben there is an aisle that according to Upton (1979) is the ultimate boundary between private and public spaces.

A study by Aziz, Siswanto, Sueca \& Purnama (2019) found that the dimensions of amben are frequently built with a ratio of $1: 1$, while pangkeng can be selected $1: 1,2: 3,3: 4$, or $4: 5$. The variation of the ratio of pangkeng is caused by the private character of this space so that a pangkeng's occupant can choose the dimension based on his/her needs. Meanwhile, the amben's dimension is very rigid reflecting social character from the discussion. In this space, someone's position is always in a sitting position to have discussions and maintain equality in it, there is no parts proceeding or being longer than the other. If there is one longer part, the width side of that 
Table 1. The Sample of Vernacular Houses in Indonesia

\begin{tabular}{|c|c|c|c|c|}
\hline No & Ethic & House & Province & Literature \\
\hline 1 & Aceh & Rumoh Aceh & Aceh & Haikal and Syam, 2019 \\
\hline 2 & Arfak & Rumah Kaki Seribu & Papua & Fauziah, 2014 \\
\hline 3 & Asmat & $\begin{array}{l}\text { Male (jew)/communal house/ceremony } \\
\text { house and fimaly house }\end{array}$ & Papua & Fauziah, 2014 \\
\hline 4 & Atoni & Typical Atoni house & East Nusa Tenggara & Nas, 1998 \\
\hline 5 & Bali & Typical Balinese house & Bali & Mashendra, 2016 \\
\hline 6 & Banjar & Bubungan Tinggi & South Kalimantan & Aqli, 2011 \\
\hline 7 & Chinese & Typical Chinese house & $\begin{array}{l}\text { West Klimantan, Bangka Belitung } \\
\text { Island, and Riau Islands }\end{array}$ & Suliyati 2011; Hardianti 2017 \\
\hline 8 & Dani & $\begin{array}{l}\text { Male house, female house, communal } \\
\text { house }\end{array}$ & Papua & Fauziah, 2014 \\
\hline 9 & Dawera-Dawelor & Typical Dawera-Dawelor house & Maluku & Nas, 1998 \\
\hline 10 & Dayak & Betang & $\begin{array}{l}\text { West kalimantan, Central } \\
\text { Kalimantan, South Kalimantan, East } \\
\text { Kalimantan, North Kalimantan }\end{array}$ & Johansen, 2014 \\
\hline 11 & Duamu & Stilt House on water and boathouse & Riau Islands & Faisal, 2018 \\
\hline 12 & Java & $\begin{array}{l}\text { Joglo, Limasan. Kampung, and } \\
\text { Panggang Pe }\end{array}$ & $\begin{array}{l}\text { Central java, Yogyakarta, and East } \\
\text { Java }\end{array}$ & $\begin{array}{l}\text { Sardiono and Nugroho, 2015; } \\
\text { Subyantoro, 2011; Hidayatun, 1999; } \\
\text { Kartono, 2005; Lihawa, Suwarno, } \\
\text { and Nuryanti, 2006; marcilia dan } \\
\text { Ohno, } 2012\end{array}$ \\
\hline 13 & Leboya & Gadang & East Nusa Tenggara & Nas, 1998 \\
\hline 14 & Malay & Typical Malay house and Bandung & $\begin{array}{l}\text { Riau, jambi, Riau Islands, North } \\
\text { Sumatera, and west Kalimantan }\end{array}$ & Arifin, 2017; Sulaiman, 2017 \\
\hline 15 & Maybrat & $\begin{array}{l}\text { Unmarried male house, unmarried } \\
\text { female house, and treehouse }\end{array}$ & Papua & Fauziah, 2014 \\
\hline 16 & Mee & $\begin{array}{l}\text { Male house (yame owa), female house } \\
\text { (yagamo owa), communal house, } \\
\text { ceremonial house (yuwo owa), forest } \\
\text { house (dada owa) }\end{array}$ & Papua & Fauziah, 2014 \\
\hline 17 & Minahasa & $\begin{array}{l}\text { Old Type and New Type of Minahasa } \\
\text { House }\end{array}$ & North Sulawesia & $\begin{array}{l}\text { Lihawa, Suwarno, and Nuryanti, } \\
\text { 2006; Toisi and John, } 2012\end{array}$ \\
\hline 18 & Mingkabau & Gadang & West Sumatera & Nurdiah, 2011 \\
\hline 19 & Moile & Ibeiya & West Papua & $\begin{array}{l}\text { Hematang, Setyowati, and Hardiman, } \\
2014\end{array}$ \\
\hline 20 & Osing & Typical Osing House & East Java & Priyotomo, 1999; Suprijanto, 2002 \\
\hline 21 & Palembang & Limas and Rakit & South Sumatera & $\begin{array}{l}\text { Aziz, Siswanto, Sueca, and Purnama, } \\
2019\end{array}$ \\
\hline 22 & Seram & Typical Seram House & Maluku & Wattimena, 2014 \\
\hline 23 & Sunda & Typical Sunda House & Banten and West Java & Triyadi and Harapan, 2008 \\
\hline 24 & Tana Ai' & Typical Tana Ai’ House & East Nusa Tenggara & Nas, 1998 \\
\hline 25 & Aceh & Rumoh Aceh & Aceh & Haikal and Syam, 2019 \\
\hline 26 & Arfak & Rumah Kaki Seribu & Papua & Fauziah, 2014 \\
\hline 27 & Asmat & $\begin{array}{l}\text { Male (jew)/communal house /ceremony } \\
\text { house and family house }\end{array}$ & Papua & Fauziah, 2014 \\
\hline 28 & Atoni & Typical Atoni house & East Nusa Tenggara & Nas, 1998 \\
\hline 29 & Bali & Typical balinese house & Bali & Marhendra, 2016 \\
\hline
\end{tabular}

part will be occupied by people with higher social status and it may cause some dynamic changes in the process of decision making. It is also supported by the fact that the 1:1 dimension is prioritized on amben is floor dimension, which becomes a place of gather and discussion, not the wall dimension.

Based on the above description, we actually able to create a typology of vernacular houses in Indonesia based on its floor plan flexibility. As we illustrated in fugure 2, we identified five types of Indonesian vernacular houses plan flexibility. First (figure a), houses with the highest flexibility without internal partitions. Examples of these houses are houses from Seram Island, Toba, and simple houses from several areas in the northern part of Sulawesi (for example older form of Minahasan house and houses of Kaili from Central Sulawesi). The second type is the houses with one or two large spaces with several small spaces. Large flexibility spaces are mixed with small flexibility spaces. A typical example of this house is the Javanese house. The third type is houses with evenly sized plans. The flexibility of these houses is less than the previous type. The majority of Indonesian vernacular houses fall into this category. Some 
examples are Malay houses and limas houses. The fourth type may be exclusively the Balinese house. These are houses with less flexibility because they are not only partitioned into several spaces, the partitions impossible to break because the spaces are distributed into small houses, marked the Balinese houses as a renowned modular house. The fifth type is the most inflexible house. Users of the house should lower their bodies in the house and there is not much space for movement inside. Ibeiya houses are a typical example of this type.
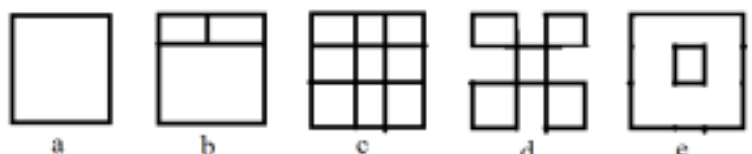

Fig. 2. Typology of Indonesian vernacular houses based on plan flexibility. From left to right: (a) house without partition, (b) house with several large spaces and small spaces, (c) house with small spaces, (d) house with small spaces, separated by outdoor space, (e) house with one small space

\section{Distance from the Ground/Water}

Limas houses are stilt houses with a square or rectangular shape and almost 3 meters of height, and they are supported by 32 stilts made of unglen wood (Dina, 2015). Stilt house type is a type commonly found in swampy areas of Sumatera, Kalimantan, and Sulawesi. The height of stilt houses being taller than human height shows that the pit of the house can be used for daily activities. Thus, the pit of most limas houses is used not only for neighborhood and family gatherings but also for additional spaces, as boarding space or storage.

The elevated pit has several various functions. In the society with kayau (headhunting) culture and inter tribe wars like the one in Kalimantan to Papua before the $19^{\text {th }}$ century, when it was finally the practices of mengayau and tribal war were dismissed by the Dutch in Kalimantan, the tall pit was a fortress. The lower pit made the enemy possible to get into it in the evening and stab the sleeping residents from under. The elevated pit was to avoid the attack from the enemy because they had to use long spares which could collide with the stilts, which made the residents awake to be ready for the threat. When awake, because of the higher position, the residents had a better strategy to counterattack the enemy. This might be an alternative explanation why in limas house, bengkilas (floor) in the middle, where activities of parties, meetings, and traditional ceremonies; then the backside bengkilas which functions for sleeping and rest, had higher platform than bengkilas closer to the porch where activities are more lively because it was a working area. This might also explain why Torajan houses even were considered as a place or area of evil so that it had to be avoided as possible, although a lower pit was always at a higher position as a cosmological requirement (Dewi, 2003). The same as in limas, Tongkonan (Torajan houses) also has split level floors with the highest level for more private space (tangdo space) of $2.00 \mathrm{~m}$ high (middle part) and 2.3.m high for backside part (Parung, Antariksa, \& Suryasari, 2016). Another split level floor house is Bubungan Tinggi from Banjar of South Kalimantan (Aqli, 2011).

Another kind of vernacular houses uses hollow as a place for cattle. Leboya from Sumba and Sopo from Toba use pit (lei bungan) for cattle (Nas, 1998). The cattle can be fed from the ground or gap of wooden boards. Organic waste emitted from the above part of the house can be thrown away downward and be consumed by cattle in the pit. The pit for cattle is relatively lower, around $1.6 \mathrm{~m}$ in Sopo. A pit in a stilt house is very helpful for ventilation because it makes the wind with high velocity can pass through the houses, instead of colliding the house (Darragh, 2012). It is very important for the houses in an open space that can be exposed to wind with high speed like coastal or prairie areas. Another function of the pit covers shade enhancement, home temperature decline, and protection from floods or wild animals (Sulaiman, 2016).

Based on the above description, we can create a typology of Indonesian vernacular houses based on their position relative to the ground. There are four types in this typology. In figure 3, we schematically illustrated this typology. First, houses embedded to the ground. These houses adapted to high earthquake potential in Central and East Java. Interestingly, however, houses from the Sundanese area not embedded to the ground. They use another way to adapt to the earthquake, using flexible columns (Triyadi \& Harapan, 2008). Sundanese and myriad houses from many parts of Indonesia belong to the second type, houses with the low pit. Some houses have a very low pit, just allowing chickens and small animals to enter. Some houses have high pit to allow large animals like pigs and dogs. Still, humans in standing positions unable to enter these pits. Houses, where human able to enter the pits, belong to type $\mathrm{d}$ houses. The houses in this type are betang house from Kalimantan and many houses from the jungle part of Papua (e.g Rumah Kaki Seribu (Thousand Legs House) from Arfak ethnic). Houses belong to type C are houses with split level floors. Not many houses from Indonesia have split level floors, limas, Bubungan Tinggi, and Tongkonan. 


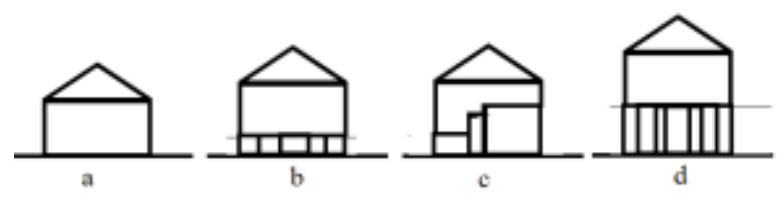

Fig. 3. Typology of Indonesian vernacular houses based on distance from the ground. From left to right: (a) house embedded to the ground, (b) house with low pit, (c) house with split level floors, (d) house with large pit, accessed by standing human.

\section{Gendered Space}

Gender segregation on the pattern of house spaces is considered universally taking women more private than men. Spaces for men are in the front part while spaces for women are at the backside. This is because men are given a role as workers and hunters while women are as household takers and food keepers. However, on Laboya houses in Sumba, spaces for men and women are even adjacent, left and right (Nas, 1998). Another type of house could be Asmat, Mee, Dani, and Maybrat houses from Papua, where there is actually a female house and a male house (jew), a house exclusively for each gender (Fauziah, 2014). Male houses located in a strategic position for guarding the community, hence collectively, the compound structured like a circle. The typology presented below.

Generally, the central part of the house is the main part of a house. Though, Tana Ai' houses from Flores even have the garden (yard) as the main part of a house (Nas, 1998). It is based on the more unique belief that forest is the origin of men, while a house is the origin of women. They both met in the garden (yard), which could be considered as semi-forestsemi-house form. As a result, gender domination in Tana 'Ai houses is against the common gender relation that the family head is a man. Because women are the house owner, usually the family head of Tana 'Ai houses is a woman. The same thing from Minang culture, in which a mother is the center of a family. In gadang houses, female members live inside the house, but men are just allowed to get in at night (Nurdiah, 2011).

The typology created from the above description could be in five types. First, a house without a clear gender segregation. Second, a house with a male space in front of the female space. Usually, males gathered in the front part of the house, such as in hajatan, usual in Malay culture, while females in the back part of the house. Usually, they also prepared the dining together. The third type, specific to Laboya house, where male and female spaces are side by side. The fourth type, usually found in Papua and West
Papua, where males and females have a specific house and met only when they have important family or communal business. Yet, there is another type of house, maybe unique to matriarchial lineage such as Minangkabau and Tana Ai' where the female is the owner of the house while males should work outside the house, or even outside the country (nagari) such as in Minangkabau.

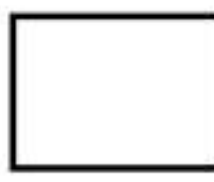

a

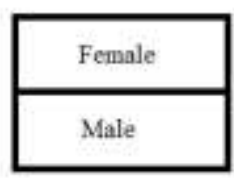

b

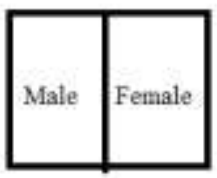

c

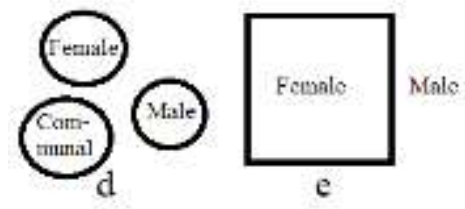

Fig. 4. Typology of Indonesian vernacular houses based on gender segregation. From left to right: (a) house without gender segregation, (b) house with a male in front and female in the back side, (c) house with male and female side by side, (d) houses compound with the male, female, and communal house

Houses of Toraja and Sumba are houses prioritizing communal dining. The unique characteristic of Torajan houses is the presence of buffalo horns that may be extensive and shows the social status of the residents. It is reasonable because buffalo horns symbolize the ability of them to provide the surrounding people with dishes in the form of beef and pork. In this case, the size of living space (padang) where people dine together is very significant. The bigger the living space is, the more people can gather for dining (Twiss, 2008). Because the size cannot be modified while the number of people can be in a huge number, it is frequently that people with high social status may dine in the space and the others have meals in other spaces. Prioritization of communal feasts was also significant in Malay houses across Sumatra, the Malaysian peninsula, and the western and northern coast of Kalimantan. Research on Malay houses (Ariffin, 2017) and limas houses (Aziz, in press) found that the verandah area in Malay houses built by feast modules for four people and bengkilas and gegajah areas in limas houses with feast module for eight people. The size likely corresponds to the collectivism level in society (Aziz, in press).

The kitchen position at the backside looks to be a universal standard for home design. However, there are some vernacular houses in Indonesia that opposed it. The kitchen Ibeiya houses in Papua is on the left 
and right. Atoni houses in Timor, have the kitchen $n$ front of the house. Leboya Houses in Sumba have it in the center of the house (Nas, 1998).

In gadang houses, partitioned spaces are more than Malay houses, but gadang houses do not have a porch and they do not have mother space (one multifunctioned space) and specific space for the kitchen (Sulaiman, 2016). It may be caused by the function of a house is more as separated family aspects while socialization is done outside.

Based on the above description, we can outline a typology of Indonesian vernacular houses based on kitchen position relative to the house (figure 5). The first type, the kitchen is in the back, even separated from the main house. The second type, specific to Atoni houses from Timor, kitchen is placed in front of the house. The third type, Ibeiya houses from West Papua, kitchen is placed on left and right. The fourth type has a kitchen in the center, such as in Leboya houses in Sumba. The last type is gadang house, with no specific space functioned as the kitchen.

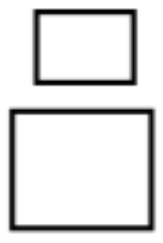

a

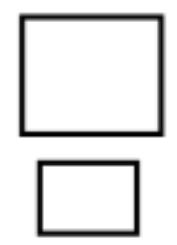

b

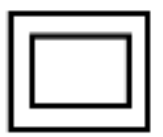

d

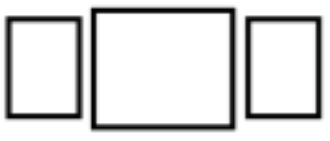

$\mathrm{c}$

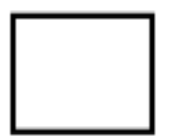

c

Fig. 5. Typology of Indonesian vernacular houses based on kitchen position relative to the house. From left to right: (a) kitchen in the back of the house, (b) kitchen in the front of the house, (c) kitchen in the sides of the house, (d) kitchen in the center of the house, (e) house without specific space for kitchen

\section{House Mobility}

There is also a unique space composition on some vernacular houses in Indonesia. In the Duanu tribe in Riau, the house of a family consists of two: one permanent house over the sea surface, and the other moves as a boat. The house over the sea is the one with $6 \times 6 \mathrm{~m}$ square built with stilts over the water with two spaces, i.e. main space and kitchen. In the main space, the activities done are to rest, welcome guests, repair the fish catching tool, sleep, and have meals. The porch with $1.5 \mathrm{~m}$ width is used as the port and the spot to attach boats. The boathouse itself is 6$7.5 \mathrm{~m}$ length, is used as a place for residence, cooking, and wedding (Faisal, 2018).

Malay houses have a mobility aspect, though with limited frequency. In Malay culture, there is a house-lifting ceremony to move a house from one place to another, sometimes to a different village (Sulaiman, 2016). House lifting may happen because of death, the baby born or land selling. The activity to move the house is possible if the house is quite light and able to be supported by some people and be covered by the basic space of the house. Moreover, the house is possible to split and carried in parts.

Hence based on mobility, there are three types of houses, namely permanent houses, semi-mobile houses, such as Malay houses, and complete mobile houses, like Duanu boat-houses. Bandung houses from Kapuas river in West Kalimantan and rakit houses from Musi river in South Sumatra also belong to the third type.

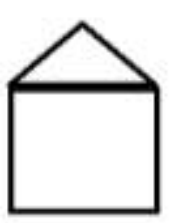

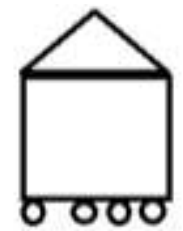

b

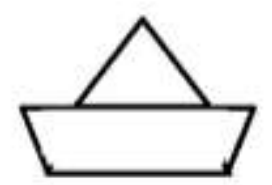

c
Fig. 6. Typology of Indonesian vernacular houses based on mobility. From left to right: (a) permanent house, (b) semimobile house, and (c) completely mobile house

\section{Sunlights and Air Circulation}

A lot of vernacular houses in Indonesia have a north-south orientation to maximize sun rays. The north-south orientation is common because the day activities are inside houses that need adequate sunlight (Amin, Siregar, \& Narhadi, 2016). Even Chinese houses tried to faced south for the same reason (Suliyati, 2011). The orientation is modified by various meanings. As an example, Javanese houses in Yogyakarta are made facing north-south to pay respect to Nyi Roro Kidul (south) and The Ruler Gennie of Mount Merapi (North). Still, DaweraDawelor houses from Southeast Maluku face westeast (Nas, 1998). While Chinese though south is the best orientation because it is the source of all good things. Aceh house also faced west-east as the symbol of Islamic spiritual orientation (qiblah) (Haikal and Syam, 2019). Another house simply oriented for more pragmatic purposes such as transportation. For example, limas houses in Palembang and Malay houses in Pontianak usually faced roads or rivers since these are the main transportation routes. Houses in fishermen communities faced sea for the same reason. Hence, the typology consists of three types: houses without specific orientation, houses with a north-south orientation such as Javanese houses in Yogyakarta, and houses with a west-east orientation such as Aceh and Dawera-Dawelor houses. 


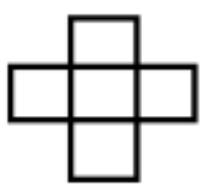

a

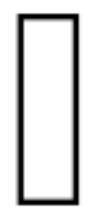

$\mathrm{b}$

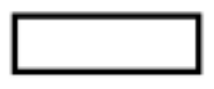

$\mathrm{c}$
Fig. 7. Typology of Indonesian vernacular houses based on direction faced. From left to right: (a) no specific orientation, (b) north-south orientation, and (c) east-west orientation

A lot of vernacular houses in Indonesia have extended openings to maximize ventilation. Malay houses in Riau and Jambi have wide windows and are at the body height so that the air can circulate, from and into the houses (Darragh, 2012). On the other extreme end, Tobelo from Halmahera are very enclosed, particularly at the backside for the kitchen (Nas, 1998). The house with enclosed type is created as an adaptation for high altitude living. Rumah Gadang from Minangkabau only have openings in front of the house, while Tongkonan has ones in front and back of the house. This made four kinds of houses based on opening extensivity: houses with openings in all sides of the house, houses with openings in two sides of the house (such as Tongkonan), the house with openings only on one side such as Gadang house, and houses without openings, such as Tobelo houses. The typology is actually almost the same as the one of Faisal, et al (2012). Faisal et al (2012) typology consists of four types. Furthermore, Faisal et al (2012) added houses with vertical ventilation, where air circulates from lower part to the top of the house, instead of cross ventilation or one direction ventilation. So, we added this fourth type to our typology. An example of this type is Nias houses. Dani houses, Bali Aga houses, and Sasak houses were also examples of the houses without ventilation.

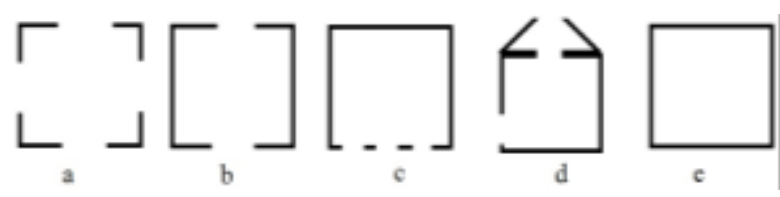

Fig. 8. Typology of Indonesian vernacular houses based on opening extensivity. From left to right: (a) openings on all sides, (b) openings on two adjacent sides, (c) openings on one side, (d) opening in bottom and peak of the house, and (e) without openings

The presence of the aisles has significant variations based on people's beliefs. Minahasa houses have aisles directly connecting the front door and the back one due to the belief that danger can easily pass through when it gets in (Lihawa, Suwarno, \& Nuryanti, 2006). Even the stairs are assembled to the side in order that people going out from the house do not distract the movement of the danger. Javanese houses and Chinese houses, on the other hand, take this design very bad. Both strongly oppose the aisle that directly connects the front door and the one at the back for different reasons. For Chinese houses, the aisle blocked will catch the fortune that it will not easily leave. The existence of an aisle will build positive energy into the house (Hardianti, 2017). For Javanese houses, the meaning is more practical, to confirm the privacy in the houses.

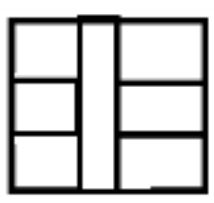

a

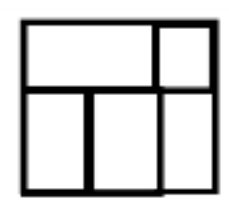

b
Fig. 9. Typology of Indonesian vernacular houses based on aisle's existence. From left to right: (a) house with aisle, (b) house without an aisle.

\section{Semi-Public Space}

The porch is a space in front of a house important as a transition between semi-public and public spaces. On the porch, guests are to sit or show performance. The size of it is managed to cover quite large people in sitting position. Malay houses and Minahasa houses (Toisi \& John, 2012) usually provide limited areas by giving a fence and elevated from the ground that it can be accessed with a stepladder. In Malay houses, the porch is blocked with a gate lower than the height of adults, so they must bow when they enter the porch.

Yet in Javanese houses, the hall (pendopo) is left open without any fence in order that many people can gather in it and find no difficulties to reach it. Pendopo must be provided in Javanese houses. A house without pendopo is seen as a tree without its trunk that it cannot be called as a house (Prijotomo, 1999). It must be considered that, in Javanese houses, the height dimension is not preferred. That is because the Javanese language does not recognize space concepts. The sole concept that is close to it is nggon, meaning 'place', refers to the two-dimension area (Kartono, 2005).

Furthermore, a porch is not elevated but remains on the ground, as same as the other part of the house. This space is interpreted as the center of communality, in which higher-level groups (priyayi) are able to collect and arrange a meeting with the servants and subordinates (Subiyantoro, 2011). The measurement 
of pendopo is larger and split as in Javanese houses cannot be found in Osing houses of Eastern East Java. They still have pendopo with reduced size and without stairs (Suprijanto, 2002). However, the concept of pendopo with leveling in Java is not interpreted as social stratification because levels have been reduced and pendopo is only used for socialization with anybody (Hidayatun, 2011).

Nevertheless, when someone wants to enter dalem and senthong, the size of a door is lower, the same as a gate of the porch in Malay houses. The purpose of the lower door frame is the same so that the guests who enter will look down and bow their heads as respect attitudes towards the house owner. Moreover, it is different from Malay houses where the lower side of a door has no limit, the door of dalem and senthong in Javanese houses also have borders at the bottom so that people who enter need to look down to avoid stumbling (Subiyantoro, 2011). The vast porch without rigid borders can be found in Betang Dayak houses in West Kalimantan, it is just the porch is elevated because betang houses are stilt houses and because betang is actually a communal house where several families live in (Johansen, 2014).

We can, then, identified three types of Indonesian vernacular houses based on semi-public borders. Malay houses with its fences can be considered as a house with a rigid border where semipublic space is bordered with fences and private space is bordered by a door, or at least, a curtain. Javanese houses can be considered as houses with a soft border where semi-public space opened while private space bordered by a fence or at least a reduced opening. Betang house can be considered as a house without the semi-public border with no closed border used for semi-public (verandah) and private space.

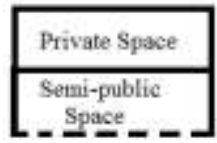

a

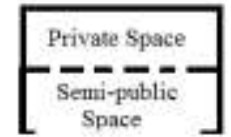

b

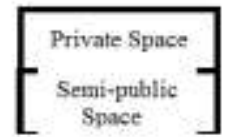

c
Fig. 10. Typology of Indonesian vernacular houses based on semi-public borders. From left to right: (a) house with a rigid border, (b) house with a soft border, (c) house without border.

Based on nine typologies above, we created a classification system to identify a house. The first typology is the first digit on this system, second typology for the second digit, and so on until each house is recognized by nine-digit system. The first typology, plan flexibility, has five variations. The second one, distance from the ground, has four variations. For example, a house designed by an identification code BCA-AAC-ABA means that the house has several large spaces and small spaces (B), have split level floors (C), without gender segregation (A), kitchen in the back of the house (A), permanent on the ground (A), oriented to east-west direction (C), openings on all sides (A), without aisle (B), and with rigid semi-public border (A). In this system, we can recognize that limas house, for example, has code CCB-AAA-AAA. Table 2 elaborate the classification system.

\section{The Role of Anthropometry}

The results above show that various activities done by the residents in vernacular houses are not different from the ones done by modern people. However, there are some variations related to the floor pattern and the size of them. It can be found the houses with little space flexibility like the ones in Arfak. A unique space solution can also be found by combining the moving and still components as Duanu houses.

The solutions came up as part of adaptation towards the environment. The houses on top of a mountain become more limited by prioritizing the fireplace function, meanwhile, the houses on the sea surface are more flexible by taking activity movement more important. Houses along the coast, swamp, and open space use stilts while houses in earthquakeprone areas are flexible and stick to the ground.

Human space and activities in the space in vernacular houses are connected not only with functions but also a social hierarchy. Spaces in tongkonan houses function for dining and keeping the dead body temporarily. Vast spaces facilitate dining held for lots of people. When the space is not adequate, the social status becomes important, when respected people are preferably to sit inside.

In lower-income society, spaces are made as flexible as possible. A simple version of tongkonan houses has two spaces, different from the high-level version that has four spaces. It is also applied to houses with lower status in many places in Sumatera. Although they have such flexibility, freedom is controlled by space measurement. Spaces in big houses are in a large size that they facilitate a lot of partitions, while spaces in small houses cannot cover many partitions that for unfortunate society one house is equal to space size in a big house.

Basically, anthropometry is very important to particular functions preferred to respond to the spatial needs of activities with some limitations forced by the environment. Anthropometry is one factor that determined space size besides the status, role, and wealth 
Table 2. The novel classification system for Indonesia vermacular houses identification

\begin{tabular}{|c|c|c|c|c|c|c|}
\hline Digit & Typology & $\mathbf{A}$ & B & $\mathrm{C}$ & D & $\mathbf{E}$ \\
\hline 1 & Plan flexibility & Without partition & $\begin{array}{l}\text { Several large and } \\
\text { small spaces }\end{array}$ & Small spaces only & \multicolumn{2}{|c|}{$\begin{array}{l}\text { Small spaces, separated One small space } \\
\text { by outdoor space }\end{array}$} \\
\hline 2 & $\begin{array}{l}\text { Distance from } \\
\text { the ground/water }\end{array}$ & $\begin{array}{l}\text { Embedded to the } \\
\text { r ground }\end{array}$ & Low pit & Split level floors & \multicolumn{2}{|c|}{$\begin{array}{l}\text { A large pit, accessed by - } \\
\text { standing human }\end{array}$} \\
\hline 3 & Gendered space & $\begin{array}{l}\text { No gender } \\
\text { segregation }\end{array}$ & $\begin{array}{l}\text { Male front. Female } \\
\text { back }\end{array}$ & $\begin{array}{l}\text { Male anf female side } \\
\text { by side }\end{array}$ & $\begin{array}{l}\text { Male house and/or } \\
\text { female house }\end{array}$ & $\begin{array}{l}\text { Female own the house, } \\
\text { male work outside }\end{array}$ \\
\hline 4 & Kitchen position & $\begin{array}{l}\text { Kitchen in the back } \\
\text { of the house }\end{array}$ & $\begin{array}{l}\text { Kitchen in front of } \\
\text { the house }\end{array}$ & $\begin{array}{l}\text { Kitchen on the left } \\
\text { and/or right of the } \\
\text { house }\end{array}$ & $\begin{array}{l}\text { Kitchen in the middle } \\
\text { of the house }\end{array}$ & $\begin{array}{l}\text { No specific space for } \\
\text { kitchen }\end{array}$ \\
\hline 5 & House mobility & Permanent house & $\begin{array}{l}\text { Semi-mobile house, } \\
\text { can be entirely or } \\
\text { disassembled to } \\
\text { move }\end{array}$ & $\begin{array}{l}\text { Completely mobile, } \\
\text { ship/boat }\end{array}$ & - & - \\
\hline 6 & Orientation & $\begin{array}{l}\text { No specific } \\
\text { orientation }\end{array}$ & $\begin{array}{l}\text { North-south } \\
\text { orientation }\end{array}$ & East-west orientation & - & - \\
\hline 7 & $\begin{array}{l}\text { Opening } \\
\text { extensivity }\end{array}$ & Openings on all sides & $\begin{array}{l}\text { Openings on two } \\
\text { sides }\end{array}$ & Opening on one side & \multirow{2}{*}{\multicolumn{2}{|c|}{$\begin{array}{l}\text { Opening on the peak of Without opening } \\
\text { the house }\end{array}$}} \\
\hline 8 & Aisle existence & With aisle & Without aisle & - & & \\
\hline
\end{tabular}

Sourse: Author's Data Analysis, 2019

of the owner (Sulaiman, 2016). Anthropometry is the basis of simple mathematical formula as the basic concept the measurement in the design and construction of traditional houses (Sulaiman, 2016). As an example, in Balinese anthropometry, the height of a door frame uses the measurement of one ulon, which is the height of an adult added with one fist (gembel) and one span of hand (cengkang) (Marhaendra, 2016) (see figure 11).

There is the prohibition to wear sandals (kasut) inside a vernacular house. Though it sounds very ordinary for the Indonesians, it is taken differently in Western culture. In the context of behavior, it is understood as an effort to maintain the house to be clean. In the spatial context, it has a function to keep the space in a house that stays flexible (Sulaiman, 2016). Several activities are clearly dirtier than others, like eating that emits more waste and crumbs than sleeping does. Yet, if all area of the floor is clean, someone may have his meal in the living space, porch, or other places. If someone wears sandals, it may make the activities difficult to do especially without a table. Likewise, when space is accessed using sandals, it will be dirtier, and someone will be difficult to have some meals in a dirty space.

In Malay houses, the width of a room is at least able to facilitate a person to sleep comfortably. As a result, its minimum width must cover at least $130 \%$ of the height of the tallest person in the house. The value of $30 \%$ can be used to facilitate the pillow and bed. It is applied to all areas in a house for sleeping such as family space (rumah ibu), and the others (Sulaiman, 2016). Meanwhile, for verandah (bengkilas in limas house), anthropometry used is the position of several people (four for Malay and eight for Palembang) encircling circular pattern of dining plates (Ariffin, 2017; Aziz, in press).

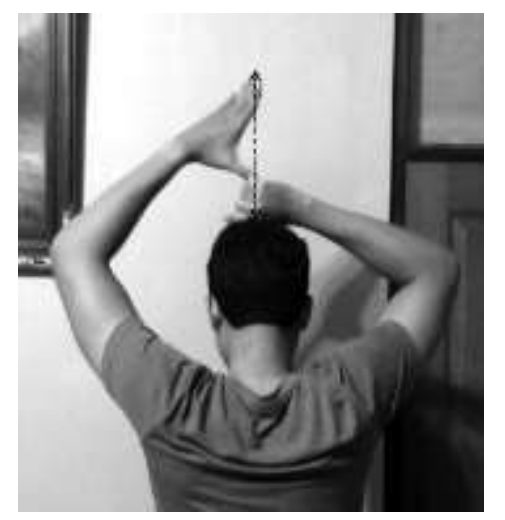

Fig. 11. The Measurement of One Ulon (Marhaendra, 2016)

The Malay houses have the characteristics of a low entrance. The entrance of this house is lowered so that anyone entering the house must bow, to symbolize a sign of homage to the occupants. The entrance is also oriented in the direction of the rising sun because it will give lots of luck to the occupants (Sulaiman, 2016). The location of the door is between the porch and the household. The household is a space specifically contains stairs to shade someone who will enter the house. It is interesting to find out whether the term "rumah tangga" in Malay architecture is the origin of the "rumah tangga" word in Indonesian meaning the unity of the residents.

The importance of the size of spaces to suit the size of a man universally is a reflection that space is an extension of humans who has a conscious relationship between body and mind (Sulaiman, 2016). In Javanese houses, the use of the body size of the head of the family as the measurement unit of house dimension becomes a reflection balance, harmony, conformity of a shelter (Hastuti, 2011). After all, the 
posture of the vertical human body reflects the vertical house segmentation as the head (roof), the body (house), the foot (pit, foundation). In Malay houses, the roof is twice the height of the pit while the pit is as high as the height of the house (figure 12).

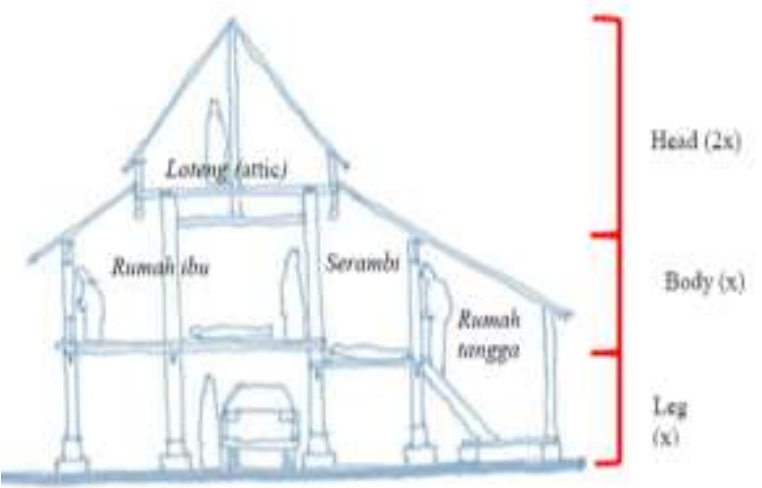

Fig. 12. The Measurement of Malay Houses on Vertical Dimension (Sulaiman, 2016)

In modern houses in the mass-built residential complex are restricted by the limited size of the land. The most important function is to facilitate the optimum spatial needs of the residents, for a private function like rest space. In its observation of housing in Yogyakarta, the community modifies spaces in a house by adding the space number, though the size will be smaller (Marcillia \& Ohno, 2012).

\section{Strengths and Weakness of Vernacular Houses}

Table 3 shows the strengths and weaknesses of a particular house as a recommendation for masshousing design. Generally, a mass-housing design will be benefited from the strengths while it can reduce weaknesses with some technical decisions. The table also implies that some spatial design ideas are implemented by adapting vernacular houses in simple residential housing. It is admitted that some solutions still have weaknesses instead of the advantages. As a result, the further implementation of simple residential housing still needs more evaluation, including its respect for the culture and needs of the local people.

In addition, we should consider that the occupants of mass-built dwelling are diverse. Vernacular people commonly give the same solutions for spatial needs, and the variations are just arisen by different social status. On the other hand, the occupants of mass-built houses have different backgrounds and needs. Some of them have many children, some work in the house, others embrace a religion different from the neighbors, and so on. It requires customization, though it is in a limited scope.
Spatial flexibility on vernacular residences as an important aspect of functionality gives a place for simple residential design in Indonesia. Although the houses do not need to be built with relatively expensive wooden materials, houses with cementbased are still able to adapt the houses of vernacular style with the functional floorplan. For example, Javanese-styled can be adapted to shape of the simple form by providing a hall (pendopo), instead of the empty yard in front of the house. The backside can be in the form of vast space used as multifunction space by the residents like kitchen, storage, and dining space. The partition can be given yet simply to facilitate mobility in narrow spaces. Another example, mass housing could be built to facilitate equality in social gatherings as limas design provided. However, private space should be placed further than limas design to overcome the weakness of this design.

\section{CONCLUSION}

This research is to build spatial typologies of Indonesian vernacular houses based on the spatial needs of human activities and to evaluate houses' strengths and weakness for human activities. Nine typologies are formulated for space flexibility, distance from the ground, kitchen position, house mobility, orientation related to the sun, gender segregation, openings extensivity, aisle existence, and privacy. Each serves the different functions of human spatial needs such as movement in a horizontal and vertical direction, space for privacy and food processing, movement on the ground/water, and gain support from natural forces such as light and air circulation. Theoretically, the finding could pave the way for more comprehensive classification systems for houses in vernacular Indonesia. Practically, considering these strengths and weaknesses, the designs can be adapted for a mass built residential development referring to local aspects, including socio-cultural aspects and physical environment.

The research has limitations. First, the classification system created is unable to differentiate several types of houses. It is possible to find houses with the same types along with all nine typologies for their similar codes. Several types have very little representation, like type E in the first typology. However, future researches are expected to explore more vernacular houses with more unique characteristics, and finally there is thorough classification to complete vernacular house databank, for easier recognition and conservation. The second limitation is the scope of the survey. Future research needs to test the applicability of vernacular design in mass-housing. Third, it is 
Table 3. A number of Characteristics of the Spatial Vernacular Houses

\begin{tabular}{|c|c|c|c|c|}
\hline Houses & Code & Characteristics & Strength & Weaknesses \\
\hline $\begin{array}{l}\text { Atoni, Timor, East } \\
\text { Nusa Tenggara }\end{array}$ & XXX-BXX-XXX & $\begin{array}{l}\text { Concentric, Inside out: } \\
\text { personal space, living space, } \\
\text { meeting space, and parent's } \\
\text { space, kitchen, fireplace, } \\
\text { water tank, and chicken } \\
\text { cage. }\end{array}$ & $\begin{array}{l}\text { Kitchen in front of the house } \\
\text { to ease waste management }\end{array}$ & $\begin{array}{l}\text { Difficult to keep the house } \\
\text { clean because the } \\
\text { consumption is done at the } \\
\text { front of the house }\end{array}$ \\
\hline Bali & DXX-XXX-XXX & $\begin{array}{l}\text { Modular with non- } \\
\text { equivalent distribution by } \\
\text { the empty land. }\end{array}$ & High flexibility for any space & $\begin{array}{l}\text { Complicating things requiring } \\
\text { large empty land, like vehicles }\end{array}$ \\
\hline $\begin{array}{l}\text { Betang, West } \\
\text { Kalimantan }\end{array}$ & XDX-XXX-XXC & $\begin{array}{l}\text { Vast portch, without } \\
\text { borders, Parallel spaces } \\
\text { behind the porch for each } \\
\text { family }\end{array}$ & $\begin{array}{l}\text { Adaptation to forest living and } \\
\text { environment supervision aid }\end{array}$ & $\begin{array}{l}\text { The paltform is too high that it } \\
\text { may be dangerous for a family } \\
\text { with dhildren. }\end{array}$ \\
\hline Duanu, Riau & $\begin{array}{l}\text { Boathouse: XXX-XCX- } \\
\text { XXX }\end{array}$ & $\begin{array}{l}\text { Two houses. Stilt houses } \\
\text { over the water and } \\
\text { boarthouses }\end{array}$ & $\begin{array}{l}\text { High mobility without leaving } \\
\text { the houses }\end{array}$ & Not practical for life on land \\
\hline $\begin{array}{l}\text { Ibeiya, Arfak, West } \\
\text { papua }\end{array}$ & EXX-CXX-XXX & $\begin{array}{l}\text { Kitchen on the left and rifht } \\
\text { sides }\end{array}$ & $\begin{array}{l}\text { Adaptable to avoid the cold } \\
\text { weather of highland }\end{array}$ & $\begin{array}{l}\text { Activities in the house done } \\
\text { by sitting }\end{array}$ \\
\hline Joglo. Java & BAX-XXX-XBB & Vast porch and kichen & Flexibility for social needs & $\begin{array}{l}\text { Vacant and quiet when not in } \\
\text { use }\end{array}$ \\
\hline Leboya, Sumba & XBC-DXX-XXX & $\begin{array}{l}\text { Two entrances. Left and } \\
\text { right doors }\end{array}$ & $\begin{array}{l}\text { Gender equality, Adaptive } \\
\text { towards strong wind and clean } \\
\text { from organic waste }\end{array}$ & $\begin{array}{l}\text { Basically, the same as two } \\
\text { pairs of flats, Illness risk from } \\
\text { cattle under and inorganic } \\
\text { waste not being decomposed. }\end{array}$ \\
\hline $\begin{array}{l}\text { Limas, Sumatera } \\
\text { Selatan }\end{array}$ & CCB-AAA-AAA & $\begin{array}{l}\text { The meeting space is square } \\
\text { on the left and right sides. } \\
\text { Private space at the } \\
\text { backside of the meeting } \\
\text { space. }\end{array}$ & $\begin{array}{l}\text { Facilitate equality in a } \\
\text { discussion }\end{array}$ & $\begin{array}{l}\text { Private space too close to the } \\
\text { meeting space that cannot be } \\
\text { used when the meeting sapace } \\
\text { is used. }\end{array}$ \\
\hline Malay, Riau & XXX-XBX-AXA & $\begin{array}{l}\text { Lightweight houses and } \\
\text { easily removed bodyhigh } \\
\text { windows. }\end{array}$ & Good lighting and ventilation & $\begin{array}{l}\text { Not possible for heavy } \\
\text { materials }\end{array}$ \\
\hline $\begin{array}{l}\text { Minahasa, North } \\
\text { Sulawesi }\end{array}$ & XXX-XXX-XAX & $\begin{array}{l}\text { Houses of "tusuk sate" (at } \\
\text { the point of T-junstion) with } \\
\text { the hall from the front door } \\
\text { to the back door }\end{array}$ & $\begin{array}{l}\text { Good and equally distributed } \\
\text { ventilation }\end{array}$ & $\begin{array}{l}\text { Complicating the existence of } \\
\text { kitchrn of left-right separation }\end{array}$ \\
\hline Seram, Maluku & AXX-XXX-XXX & A space for a house & $\begin{array}{l}\text { Significantly high flexibility. } \\
\text { Good ventilation }\end{array}$ & $\begin{array}{l}\text { Very simple house due to no } \\
\text { partition }\end{array}$ \\
\hline $\begin{array}{l}\text { Sopo, Toba, Sumatera } \\
\text { Utara }\end{array}$ & ABX-XXX-XXX & High pit used for cattle & $\begin{array}{l}\text { Adaptive towards strong wind } \\
\text { and clean from organic waste }\end{array}$ & $\begin{array}{l}\text { Illness risk from cattle under } \\
\text { and inorganic waste not being } \\
\text { decomposed }\end{array}$ \\
\hline Tana'Ai, Flores & XXE-XXX-XXX & $\begin{array}{l}\text { The main part is the house } \\
\text { yard (garden) }\end{array}$ & $\begin{array}{l}\text { Green due to maintained and } \\
\text { planted empty land }\end{array}$ & $\begin{array}{l}\text { Besides promoting green } \\
\text { space, no other significant } \\
\text { feature }\end{array}$ \\
\hline Tobelo, Halmahera & XXX-XXX-CXX & $\begin{array}{l}\text { The main house with a bed, } \\
\text { the big bamboo table in } \\
\text { front, and a back part } \\
\text { extension as kitchen }\end{array}$ & $\begin{array}{l}\text { Some activities done outside } \\
\text { (around the bambbo table) } \\
\text { encouraging outdoor physical } \\
\text { activities }\end{array}$ & $\begin{array}{l}\text { Very enclosed back part } \\
\text { cousing a lack of ventilation }\end{array}$ \\
\hline $\begin{array}{l}\text { Tongkonan, Sulawesi } \\
\text { Selatan }\end{array}$ & XCX-XXB-BXX & Vast middle space & Suitable for party activities & $\begin{array}{l}\text { Social stratification while } \\
\text { sitting }\end{array}$ \\
\hline
\end{tabular}

Sourse: Data analysis, 2019; note $=\mathrm{X}$ in the mean need further study

limited in the method. The literature search method needs more refined and systematical to collect more literature and research action to confirm its validity.

\section{REFERENCES}

Amin, A., Siregar, P., \& Narhadi, J. (2016). Study Pencahayaan Alami pada Rumah Limas Panggung Palembang (Simulasi dengan Program Ecotect 5.0). Teknosain, 22(9), 629-641.
Aqli, W. (2011). Anatomi Bubungan Tinggi sebagai rumah tradisional utama dalam kelompok rumah Banjar. NALARs, 10(1), 71-82.

Ariffin, S. I. (2017). Made to Order - A Place Called Home. In S. R. Ju (Ed.), Southeast Asian Houses: Expanding Tradition. Seoul: Seoul Selection.

Ateshin, H. M. (1987). A Conceptual Framework for "Islamic Architectural" Education. Disertasi. The University of Sheffield. 
Aziz, I (in press). Comparing the Philosophical and Social Dimensions and Their Relationship with the Anthropometrical Characteristics in the Bengkilas of Limas Vernacular Houses from Southern Sumatra.

Aziz, I., Siswanto, A., Sueca, N. P., \& Purnama, D. H. (2019). The Traditional Architecture of Palembang Limas House: Evaluation of Physical Proportion of Palembang Limas House with Three Bengkilas in Seberang Ulu Palembang. International Journal of Engineering and Advanced Technology, 9(1), 3631-3635.

Banjarmasin Post. (2018). Ini Kata Perbankan Soal Rumah Bersubsidi Berarsitektur Banjar. Diakses dari http://banjarmasin.tribunnews.com/ 2018/05/07/ini-kata-perbankan-soal-rumah-bersubsidi-berarsitektur-banjar

Brown, G. M., \& Paddock, C. I. (2011). Chacoan and Vernacular Architecture at Aztec Ruins: Putting Chaco in its Place. KIVA: Journal of Southwestern Anthropology and History, 77(2), 203-224. https://doi.org/10.1179/kiv.2011.77.2.004

Darragh, J. C. (2012). Experience Generated Design : An Approach to Restore Balance in a Culture of Comfort. Thesis. The University of Tennessee.

Dewi, N. (2003). Wantah Geometri, Simetri, dan Religiusitas pada Rumah Tinggal Tradisional di Indonesia. Jurnal Permukiman "Natah", 1(1), 29-43.

Dina, R. R. (2015). Makna dan Nilai Filosofis Masyarakat Palembang yang Terkandung dalam Bentuk dan Arsitektur Rumah Limas. Ekspresi Seni: Jurnal Ilmu Pengetahuan Dan Karya Seni, 17(2), 275-282.

Faisal, G., Suwarno, N., \& Wihardyanto, D (2012). Tipologi Ventilasi Bangunan Vernakular Indonesia. Jurnal Arsitektur Universitas Bandar Lampung, 27-35.

Faisal, G. (2018). Transformasi Hunian Vernakular Suku Duanu, Pesisir Timur Sumatera. Jurnal BAPPEDA, 4(1), 43-50.

Fauziah, N. (2014) Karakteristik Arsitektur Tradisional Papua. Simposium Nasional Teknologi Terapan (SNNT) 2, A-19-29

Glassie, H. (1990). Architects, Vernacular Traditions, and Society. TDSR, 2, 9-21.

Haikal, R., \& Syam, H. M. (2019). Makna Simbolik Arsitektur Rumoh Adat Aceh (Studi Pada Rumah Adat Aceh di Pidie). Jurnal Ilmiah Mahasiswa Fakultas Ilmu Sosial \& Ilmu Politik, 4(4), 1-11.

Hardianti, A (2017). Feng Shui pada Tata Ruang Rumah Bergaya Indische Empire di Roemah Martha Tilaar. Universitas Negeri Yogyakarta.
Hastuti, D. L. (2011). Status dan Identitas Sosial Saudagar Batik Laweyan dalam Interior Dalem Indis di Awal Abad ke-20. Dewa Ruci, 7(1), 140-160.

Hematang, Y. I. P., Setyowati, E., \& Hardiman, G. (2014). Kearifan lokal Ibeiya dan Konservasi Arsitektur Vernakular Papua Barat. Indonesian Journal of Conservation, 3(1), 16-25.

Hidayah, Z (2015). Ensiklopedia Suku Bangsa di Indonesia. Jakarta: Yayasan Obor Indonesia.

Hidayatun, M. (1999). Pendopo dalam Era Modernisasi: Bentuk, Fungsi dan Makna Pendopo pada Arsitektur Tradisional Jawa dalam Perubahan Kebudayaan. Dimensi Teknik Arsitektur, 27(1), 37-43.

Johansen, P. (2014). Arsitektur Rumah Betang (Radakng) Kampung Sahapm. Patanjala, 6(3), 461-474.

Kartono, J. L. (2005). Konsep Ruang Tradisional Jawa dalam Konteks Budaya. Dimensi Interior, 3(2), 124-136. https://doi.org/10.9744/interior. 3.2.

Lihawa, H., Suwarno, N., \& Nuryanti, W. (2006). Tipologi Arsitektur Rumah Tinggal: Studi Kasus Masyarakat Jawa Tondano (Jaton) di Desa Reksonegoro Kabupaten Gorontalo. Tesis. Universitas Gadjah Mada.

Marcillia, S. R., \& Ohno, R. (2012). Learning from Residents' Adjustments in Self-built and Donated Post Disaster Housing after Java Earthquake 2006. Procedia-Social and Behavioral Sciences, 36, 61-69. https://doi.org/10.1016/j.sbspro. 2012.03.007

Marhaendra, T. (2016). Striving for Modernized Balinese Metrics (Gegulak). Journal of Human Ergology, 45, 1-10.

Nas, P. J. M. (1998). The house in Indonesia; Between globalization and localization. Bijdragen Tot de Taal-, Land- En Volkenkunde / Journal of the Humanities and Social Sciences of Southeast Asia, 154(2), 335-360. https://doi. org/10.1163/22134379-90003901

Nurdiah, E. A. (2011). Studi Struktur dan Konstruksi Rumah Tradisional Suku Batak Toba, Minangkabau dan Toraja. Surabaya.

Parung, C., Antariksa, \& Suryasari, N. (2016). Pola Ruang dalam Banua Tongkonan dan Banua Barung-Barung di Dusun Tonga, Kelurahan Panta'nakan Lolo, Toraja Utara. Jurnal Mahasiswa Jurusan Arsitektur, 4(2), 1-9.

Prijotomo, J. (1999). Griya dan Omah: Penelusuran Makna dan Signifikasi di Arsitektur Jawa. Dimensi Teknik Sipil, 27(1), 30-36.

Sardjono, A. B., \& Nugroho, S. (2015). Keragaman Perubahan pada Rumah Tradisional jawa di pedesaan. Modul, 15(2), 141-155.

Subiyantoro, S. (2011). Rumah Tradisional Joglo dalam Estetika Tradisi Jawa. Bahasa Dan Seni, 39(1), 68-78. 
Sulaiman, M. S. (2016). Challenges in the Conservation of the Negeri Sembilan Traditional Malay House (NSTMH) and Establishment of a Conservation Principles Framework. Disertasi. The University of Edinburgh.

Suliyati, T. (2011). Tradisi Feng Shui pada Kelenteng di Pecinan Semarang. Sabda, 6(1), 75-87.

Suprijanto, I. (2002). Rumah Tradisional Osing: Konsep Ruang dan Bentuk. Dimensi Teknik Arsitektur, 30(1), 10-20.

Toisi, N., \& John, K. (2012). Pengaruh Luas Bukaan Ventilasi terhadap Penghawaan Alami dan Kenyamanan Thermal pada Rumah Tinggal Hasil Modifikasi dari Rumah Tradisional Minahasa. Daseng: Jurnal Arsitektur, 1(1), 66-73.

Tratsiakovich, D. (2018). Chinese Siheyuan Architecture: Transformation of Siheyuan during 20$21^{s t}$ Centuries and Its Sustainability in the Future. Tesis. Stockholms Universiteit.
Triyadi, S., Harapan, A. (2008). Kearifan Lokal Rumah Vernakular di Jawa Barat Bagian Selatan dalam Merespon Gempa. Jurnal Sains dan Teknologi EMAS, 18(2), 123-134.

Twiss, K. C. (2008). Transformations in an early agricultural society: Feasting in the southern Levantine Pre-Pottery Neolithic. Journal of Anthropological Archaeology, 27, 418-442. https://doi.org/10.1016/j.jaa.2008.06.002

Upton, D. (1979). Toward a Performance Theory of Vernacular Architecture: Early Tidewater Virginia as a Case Study. Folklore Forum, 12, 174-176.

Wassum, R. (2013). Baby Boomer Living: Designing a Modern Continuing Care Retirement Community. Tesis. California Polytechnic State University.

Wattimena, L. (2014). Rumah Adat di Pesisir Selatan Pulau Seram, Maluku: Tinjauan Awal Etnoarkeologi. Humaniora, 26(3), 266-275. 